\title{
Evaluation of the proliferative activity of methanol extracts from six medicinal plants in murine spleen cells
}

\author{
Rodrigo Hermes Zandonai ${ }^{1}$, Fabiana Coelho², Juliana Ferreira², Ana Karla Bittencourt Mendes², \\ Maique Weber Biavatti', Rivaldo Niero", ${ }^{1,}$, Valdir Cechinel Filho, ${ }^{1,2}$, Ednéia Casagranda Bueno ${ }^{1,2, *}$
}

${ }^{1}$ Center for Chemical-Pharmaceutical Research, Master's Program in Pharmaceutical Sciences, University of Vale do Itajai, ${ }^{2}$ Center for Chemical-Pharmaceutical Research, Course of Pharmacy, University of Vale do Itajai, ${ }^{3}$ Department of Pharmacy, Federal University of Santa Catarina

\begin{abstract}
A number of natural compounds have been used as immunomodulatory agents, enabling the function of the immune system to be modified by stimulating or suppressing it. There has been increasing interest in the study of therapeutic action of plant extracts regarding their immunomodulatory activity. The aim of this study was to identify and evaluate the action of extracts of the medicinal plants Calophyllum brasiliense, Ipomoea pes-caprae, Matayba elaeagnoides, Maytenus robusta, Rubus imperialis and Vernonia scorpioides on the development of spleen cells from mice, using the in vitro cellular proliferation assay. The cells, obtained by mechanical rupture of mice spleen $\left(5 \times 10^{4}\right.$ cells $\left./ \mathrm{mL}\right)$, were incubated with methanol extracts $(10,50,100$ and $200 \mu \mathrm{g} / \mathrm{mL})$ and phytohemagglutinin (PHA, $5 \mu \mathrm{g} / \mathrm{mL})$. The basal control for proliferation consisted of cells alone, while the positive control consisted of cells and PHA. The cell culture was kept at $37{ }^{\circ} \mathrm{C}$ in $5 \% \mathrm{CO}_{2}$ for 72 hours, and cell proliferation was revealed by the blue tetrazolium reduction assay (MTT). The results were expressed as percentage of growth and were analyzed using the Kruskal-Wallis and Mann-Whitney tests. The C. brasiliense, I. pes-caprae and M. elaeagnoides extracts showed dose-dependent induction of cell proliferation, with a significant increase in cell proliferation $(\mathrm{p}<0.03)$ and percentage growth of $88.2 \%, 73.1 \%$ and $52.7 \%$, respectively, suggesting T lymphocyte stimulation. By contrast, $M$. robusta, $R$. imperialis and $V$. scorpioides extracts showed significance only with a negative percentage of growth, suggesting inhibition of cell proliferation $(p<0.04)$. Further biomonitoring studies will enable the fractions and isolated substances responsible for the immunomodulatory activities to be identified.
\end{abstract}

Uniterms: Medicinal plants. Natural products/immunomodulatories. Immunomodulation. Calophyllum brasiliense/pharmacognosy. Ipomoea pes-caprae/pharmacognosy. Matayba elaeagnoides/ pharmacognosy. Maytenus robusta/pharmacognosy. Rubus imperialis/pharmacognosy. Vernonia scorpioides/pharmacognosy.

\footnotetext{
Várias substâncias de origem natural têm sido utilizadas como agentes imunomoduladores, permitindo modificar a função do sistema imune e propiciando o estudo de atividades terapêuticas de extratos de plantas. Este trabalho objetivou identificar a atividade imunomodulatória dos extratos de seis plantas medicinais da flora brasileira, Calophyllum brasiliense, Ipomoea pes-caprae, Matayba elaeagnoides, Maytenus robusta, Rubus imperialis e Vernonia scorpioides, sobre a proliferação de células esplênicas de camundongos. As células esplênicas murinas obtidas por ruptura mecânica do baço $\left(5 \times 14^{3}\right.$ células $\left./ \mathrm{mL}\right)$ foram incubadas com os extratos metanólicos das plantas $(10,50,100,200 \mu \mathrm{g} / \mathrm{mL})$ e fito-hemaglutinina (PHA, $5 \mu \mathrm{g} / \mathrm{mL}$ ). O controle basal de proliferação foi constituído de células apenas e o controle positivo formado por células e PHA. O cultivo celular foi mantido a $37{ }^{\circ} \mathrm{C}, 5 \%$ de $\mathrm{CO}_{2}, 72$ horas, com quantificação da proliferação celular pelo ensaio de redução do azul de tetrazólio. Os resultados expressos em percentagem de crescimento foram analisados pelos testes de Kruskal-Wallis e Mann-Whitney. Os extratos de $C$. brasiliense, I. pes-caprae e M. elaeagnoides mostraram indução dose-dependente da proliferação celular $(\mathrm{p}<0,03)$, com percentagem de crescimento de, respectivamente, $88,2 \%, 73,1 \%$ e
}

\footnotetext{
*Correspondence: E. C. Bueno. Núcleo de Investigações Químico-Farmacêuticas, Curso de Farmácia - UNIVALI. Rua Uruguai, 458, bloco 17, sala 309 - Centro - 88302-202 - Itajaí - SC, Brazil. E-mail ecbueno@univali.br
} 
$52,7 \%$, sugerindo estímulo de linfócitos T. Contrariamente, os extratos de M. robusta, $R$. imperialis e $V$. scorpioides apresentaram significância apenas com percentagem de crescimento negativa, indicando inibição da proliferação celular $(\mathrm{p}<0,04)$. A continuidade no estudo biomonitorado permitirá a identificação das frações e substâncias isoladas responsáveis pelas atividades imunomoduladoras.

Unitermos: Plantas medicinais. Produtos naturais/imunomoduladores. Imunomodulação. Calophyllum brasiliense/farmacognosia. Ipomoea pes-caprae/farmacognosia. Matayba elaeagnoides/farmacognosia. Maytenus robusta/farmacognosia. Rubus imperialis/farmacognosia. Vernonia scorpioides/farmacognosia.

\section{INTRODUCTION}

The identification of therapeutic activities of plant extracts by means of chemical, pharmacological and toxicological studies is an area of growing research interest. The plant kingdom is a large reservoir of pharmacologically active molecules, and the target of investment by pharmaceutical companies searching for new active substances (Hostettmann, Queiroz Vieira, 2003), which is reflected by the large number of plant-derived medicines now commercially available (Newman, Cragg, 2007; Wagner, 2007).

The ethnopharmacological knowledge has culminated in the development of substances that have had a significant impact on current therapeutics, such as salicylic acid, atropine, pilocarpine, quinine, artemisinin, taxol, digoxin and morphine (Verotta et al., 2000; Viegas et al., 2006). Several plants found in the State of Santa Catarina, Brazil, have popular medicinal use. These include homemade alcohol, infusions, baths and homogenized preparations of fresh plant, such as: Calophyllum brasiliense - used to treat bronchitis, kidney and gastric diseases, inflammation, diabetes, varicose, diarrhea, herpes, rheumatism, hemorrhoids and chronic ulcers (Noldin, Buffon, Cechinel Filho, 2006); Ipomea pes-caprae - used to treat dermatitis caused by jellyfish, cramps, diuretic disorder, gonorrhea, inflammation and pain (Pongprayoon et al., 1989; Souza et al., 1998); Matayba eleagnoides - used to treat inflammation, pain and liver cancer (Lorenzi, 2000; Souza et al., 2007); and Maytenus robusta (Niero et al., 2006; Andrade et al., 2007) and Rubus imperialis - used in the treatment of peptic ulcer, diabetes and pain (Cechinel Filho, 2000), and also Vernonia scorpioides - used to treat skin disorders and varicose ulcers and to combat parasites (Monteiro et al., 2001).

Studies of phytochemical and biological activity have identified several compounds present in these plants, showing several activities such as antinociceptive activity against $C$. brasiliense (Silva et al., 2001; Isaias, et al., 2004; Niero et al., 2006), I. pes-caprae (Krogh et al., 1999; Souza et al., 2000), M. eleagnoides (Souza et al., 2007), $M$. robusta (Niero et al., 2001) and $R$. imperialis (Niero et al., 1999; Niero et al., 2002; Ardenghi et al., 2006), and also molluscicicidal activity against $C$. brasiliense (Gasparotto Jr. et al., 2005) and cytotoxic activity against V. scorpioides (Buskühl, 2007).

The use and development of drugs that suppress the immune system - known as immunosuppressors - has broadened due to transplantation and advances in knowledge of Clinical Immunology, which has revealed the pathophysiology of diseases caused by both exacerbation and deficiency of the immune response (Lima, 2007). The analysis of immunostimulating or immunosuppressive activity promoted by natural compounds has been determined by a host of different methodologies and models by means of in vivo and in vitro assays. The lymphocyte proliferation assay is one of the models used to assess the activity of these compounds on cell proliferation, revealing the stimulation or suppression of the activation of this cell population (Pandima Devi et al., 2003). In this model, the in vitro proliferative function of murine spleen cells and human mononuclear cells can be evaluated in the presence or absence of stimulators such as phytohemagglutinin (PHA), concanavalin A, pokeweed mitogen, lipopolysaccharide, specific antigens derived from different aggressive agents and even extracts, purified natural substances and synthetic compounds (Pandima Devi et al., 2003; Rocha, Gorescu, Beltrame, 2007).

In view of the phytochemical and biological activity studies carried out in other models, with some species obtained from Santa Catarina, as C. brasiliense, I. pescaprae, M. eleagnoides, $M$. robusta, $R$. imperialis and $V$. scorpioides, and the lack of information on the immunomodulatory activity of these plants, this study aimed to evaluate the activity of methanol extracts of these six medicinal plants on the proliferation of murine spleen cells in vitro.

\section{MATERIAL AND METHODS}

\section{Plant material collection}

The studied plants - roots of $C$. brasiliense, whole plant of I. pes-caprae, shells of M. elaeagnoides, aerial 
parts of M. robusta and R. imperialis, plus leaves and flowers of $V$. scorpioides, were previously collected in Santa Catarina, in the same place of origin and seasonal period as the specimens deposited in the Herbarium Barbosa Rodrigues, Itajaí-SC, under voucher numbers VC Filho 007, V.C. Filho 009, MTS 001, V.C. Filho 016, V.C. Filho 012, HBR and M. Biavatti 11, respectively. The methanol extracts were prepared from dried, triturated plant material. The material collected was macerated for 10 days in a closed container at room temperature, protected from light, using methanol as the fluid extractor. The material obtained was filtered and concentrated by evaporation and negative pressure. A preliminary investigation of the composition of the extracts were performed using spectroscopy methods such as infrared, ${ }^{1} \mathrm{H}$ and ${ }^{13} \mathrm{C}$ nuclear magnetic resonance, and bidimensional techniques (Krogh et al., 1999; Niero et al., 1999; Silva et al., 2000; Niero et al., 2001; Souza, 2006; Buskühl, 2007). The methanol extracts obtained were kept in the dark in desiccators, together with silica to remove the moisture. The extracts were solubilized with 2\% dimethylsulfoxide (DMSO, VETEC Química Fina LTDA, Duque de Caxias, RJ), resulting in a concentration of $1 \mathrm{mg} / \mathrm{mL}$ in DMEM culture medium (Dulbelccos's Modified Eagles Medium, Sigma Inc., St . Louis, MO, USA). These preparations were filtered at $0.22 \mu \mathrm{m}$, aliquoted and stored at $-20^{\circ} \mathrm{C}$ in the dark, until use.

\section{Spleen cell collection}

This study was conducted in accordance with the ethical standards for research involving animals, with the prior approval of the University of Vale do Itajaí (UNIVALI) Research Ethics Committee (No. 131/2006). A total of sixty male Swiss mice, weighing between 20 and 30 grams, were obtained from the vivarium of UNIVALI. The spleen cells were obtained aseptically by mechanical disruption of the capsule of the spleen of animals killed by cervical dislocation. The determination of cell concentration in a Neubauer chamber was performed after lysis of red blood cells with hypotonic shock, together with verification of cell viability by the trypan blue exclusion test (VETEC) (Boyum, 1968). Only cell suspensions with viability exceeding $90 \%$ were used.

\section{Cell culture}

The DMEM cell culture medium used was supplemented with $10 \%$ fetal bovine serum (CULTILAB, Campinas, SP), 2\% sodium bicarbonate at 10\% (Dinâmica, São Paulo, SP), 1\% L-glutamine at $200 \mathrm{mM}$ (Sigma), $1 \%$ HEPES at $10 \mathrm{mM}$ (Sigma) and $110 \mathrm{mg} / \mathrm{mL}$ sodium pyruvate (VETEC). The cell culture was performed in microtiter plates (TTP, Techno Plastic Products, Trasadingen, Switzerland) with incubation of the cells $(50,000$ cells $/ \mathrm{mL})$ and methanol extracts $(10,50,100$ and $200 \mu \mathrm{g} / \mathrm{mL})$ in the presence or absence of PHA (Sigma, $5 \mu \mathrm{g} / \mathrm{mL}$ ) for 72 hours at $37^{\circ} \mathrm{C}$ and in $5 \% \mathrm{CO}_{2}$ (Jouan, model IG150, Saint Herbain, France) (Yasni et al., 1993; Roseghini et al., 2006). The cell and mitogen concentrations were determined by the growth curve (data not shown), while the concentrations of the extracts were defined according to the literature (Wilasrusmee et al., 2002; Manosroi, Saraphanchotiwitthaya, Manosroi, 2003; Mehrotra et al., 2003). The assay revelation was performed by blue tetrazolium reduction assay (MTT), with the addition of $10 \mu \mathrm{L}$ of MTT at $5 \mathrm{mg} / \mathrm{mL}$ (Amreco, Solon, Ohio, USA) in $0.9 \% \mathrm{NaCl}$ to each well of the microplate three hours before the end of the incubation period. At the end of the incubation period, $100 \mu \mathrm{L}$ of sodium dodecyl sulfate $10 \%$ was added (SDS, Amreco) in $\mathrm{HCl} 0.001 \mathrm{~N}$ (VETEC) to each well. The plate was incubated overnight and optical density (OD) determined at $540 \mathrm{~nm}$ (Quick ELISA, Drake, São Paulo, SP) (Mosmann, 1983; Denizot, Lang, 1986).

Cell response to PHA was used as a positive control for cell proliferation, while the absence of contamination and residual staining of cells and extracts (basal control) were obtained when they were kept alone in the culture medium. The colorimetric method of MTT reduction can be used to measure cytotoxicity, proliferation and even cell activation, since the determination of the activity of mitochondrial dehydrogenase of living cells directly and proportionally represents the number of cells (Mosmann, 1983). The results were presented as a percentage of growth, according to Manosroi, Saraphanchotiwitthaya and Manosroi (2003) and Risco et al. (2003), through equation 1 . This indicator eliminates the residual reduction of MTT by cells not exposed to the extract or mitogen, as well as the background color of the methanol extract and the inter-assay variations. All the results were expressed as the mean and standard deviation of four experiments performed in triplicate.

$$
\% \text { of growth }=\frac{(\text { OD test }- \text { OD basal control })}{\text { OD basal control }}
$$

\section{Analysis and discussion of data}

The dose-response effect was evaluated by the coefficient of determination, obtained from the polynomial trend line in the order 3 , with a value of $\mathrm{R}^{2}=1.0$ for all the extracts. The data were also analyzed by the KruskalWallis and Mann-Whitney tests. 


\section{RESULTS AND DISCUSSION}

Studies with natural products involve biological activity and pharmacological assays for the screening of plant extracts, with subsequent evaluation of the fractions and isolated compounds responsible for the activity observed (Cechinel Filho, Yunes, 1998). In this context, there are several aspects to be considered when choosing a plant to be studied, one of which is its use in folk medicine (Yunes, Cechinel Filho, 2001; Yunes, Cechinel Filho, 2007). The immunomodulatory effect in the cell proliferation model has been a target of study in the search for new therapeutic agents of natural origin (Souza-Fagundes et al., 2002; Pandima Devi et al., 2003; Arokiyaraj et al., 2007; Sriwanthana et al., 2007). The activation of the immune response in this model promotes cell proliferation with an increase in the number of cells present in the culture within a defined period (Rocha, Goresco, Beltrame, 2007) and can be identified through MTT reduction by mitochondrial dehydrogenase of living cells (Mosmann, 1983).

The methanol extract of $C$. brasiliense assessed in this study induced an increase in cell proliferation (Figure $1 \mathrm{~A}$ ) in a dose-dependent response (Figure 2A). The average percentage of cell growth ranged from 5.8 to $88.2 \%$ and from 15.3 to $96.3 \%$, for the extract alone and extract together with PHA in the cell culture, respectively. The extract at 100 and $200 \mu \mathrm{g} / \mathrm{mL}$ under both cell culture conditions showed significantly higher values $(\mathrm{p}=0.02)$ than the positive control of cell proliferation $(12.2 \%)$.

PHA is the most applicable lectin in the activation of T lymphocytes in vitro, and enables the evaluation of immune response mediated by this cell type (Rocha, Gorescu, Beltrame, 2007). Thus, the results obtained with the methanol extract of $C$. brasiliense suggest that the component(s) present in the plant stimulate T lymphocyte proliferation, supposedly activating the cellular immune response. It should be noted that the study of this model against lipopolysaccharide (LPS) and other lectins such as concanavalin A and pokeweed mitogen, enable the evaluation of the effect of the extract on other cell types involved in the defense process. However, the preliminary data obtained in our study provides guidance for biomonitored follow up studies with fractions and isolated substances from plants that have shown promising results.

In previous studies, phytochemical investigations of the Calophyllum genus have shown the presence of a large variety of compounds, such as xanthones, phenolic acids, coumarins, flavonoids, biflavonoids, chalcones, benzophenones and triterpenes (Noldin, Buffon, Cechinel Filho, 2006), quercetin, gallic and protocatetic acid, hyperoside, amantoflavona (Silva et al., 2001) and betulinic acid (Bu- ffon, 2005). The tricyclic coumarin GUT-70, isolated from the bark of $C$. brasiliense, was characterized as a natural agent against cancer by inhibiting the growth of six strains of human leukemia cells, without causing inhibition of proliferation of white blood cells and normal hepatocytes (Ito et al., 2003; Kimura et al., 2005).

Immunomodulatory activity has been reported for other compounds present in C. brasiliense, when extracted from other species. For instance, the gallic acid present in other species prevents DNA oxidation, preventing cell death by accumulation of nitric oxide in the culture medium (Kuhlmann et al., 1998). The coumarin extracted from Hydrangeae dulcis folium had no effect on the response of human T lymphocytes stimulated with PHA (Shimoda et al., 1998), while triterpenes from the bark of Quercus suber proved a potent inhibitor of human lymphocyte proliferation, as well as reducing the growth of the human cancer cell strain (Moiteiro et al., 2001). Triterpenes isolated from the leaves of Justicia gendarussa also showed inhibition of human lymphocyte proliferation, with maximum inhibition of $85 \%$,when using a methanol extract of the plant (Arokiyaraj et al., 2007). Although the triterpenes reported in the literature as inhibitors of lymphocytes proliferation are also present in $C$. brasiliense, their concentration in the extract used in this study may be lower than the other compounds that stimulated cell proliferation. This finding strongly indicates a need for further studies of fractions and isolated compounds obtained from $C$. brasiliense, to identify those responsible for the toxic effects on tumor cells and cytoprotective effect in normal cells, and also those responsible for stimulating the proliferation of $\mathrm{T}$ lymphocytes, activity observed in this study.

The methanol extract of I. pes-caprae induced dosedependent proliferation of murine spleen cells (Figures $1 \mathrm{~B}$ and $2 \mathrm{~B}$ ). The average rate of cell growth ranged from 13.4 to $73.1 \%$ when the cells were treated with the extract alone, and $2.9 \%$ to $63.9 \%$ for cells treated with extract and PHA combined. Under both culture conditions, the extract at $200 \mu \mathrm{g} / \mathrm{mL}$ showed significantly higher cell growth in comparison to the positive control of cell proliferation $(12.2 \%)(\mathrm{p}=0.02)$. As observed for the methanol extract of $C$. brasiliense, the results suggest that the component (s) present in the methanol extract of I. pes-caprae stimulate the proliferation of $\mathrm{T}$ lymphocytes.

Phytochemical studies of I. pes-caprae have identified the presence of steroids, terpenoids, alkaloids and flavonoids (Souza et al., 2000), $\beta$-damascenone, E-phytol, betulinic acid, triperpenos, $\alpha$ - and $\beta$-amyrin, acetates, isoquerticinas (Pongprayoon, Bohlin, Wasuwat, 1991; Souza et al., 2000) and isoprenoids (Krogh et al., 1999). Although triterpenes and flavonoids have been described 

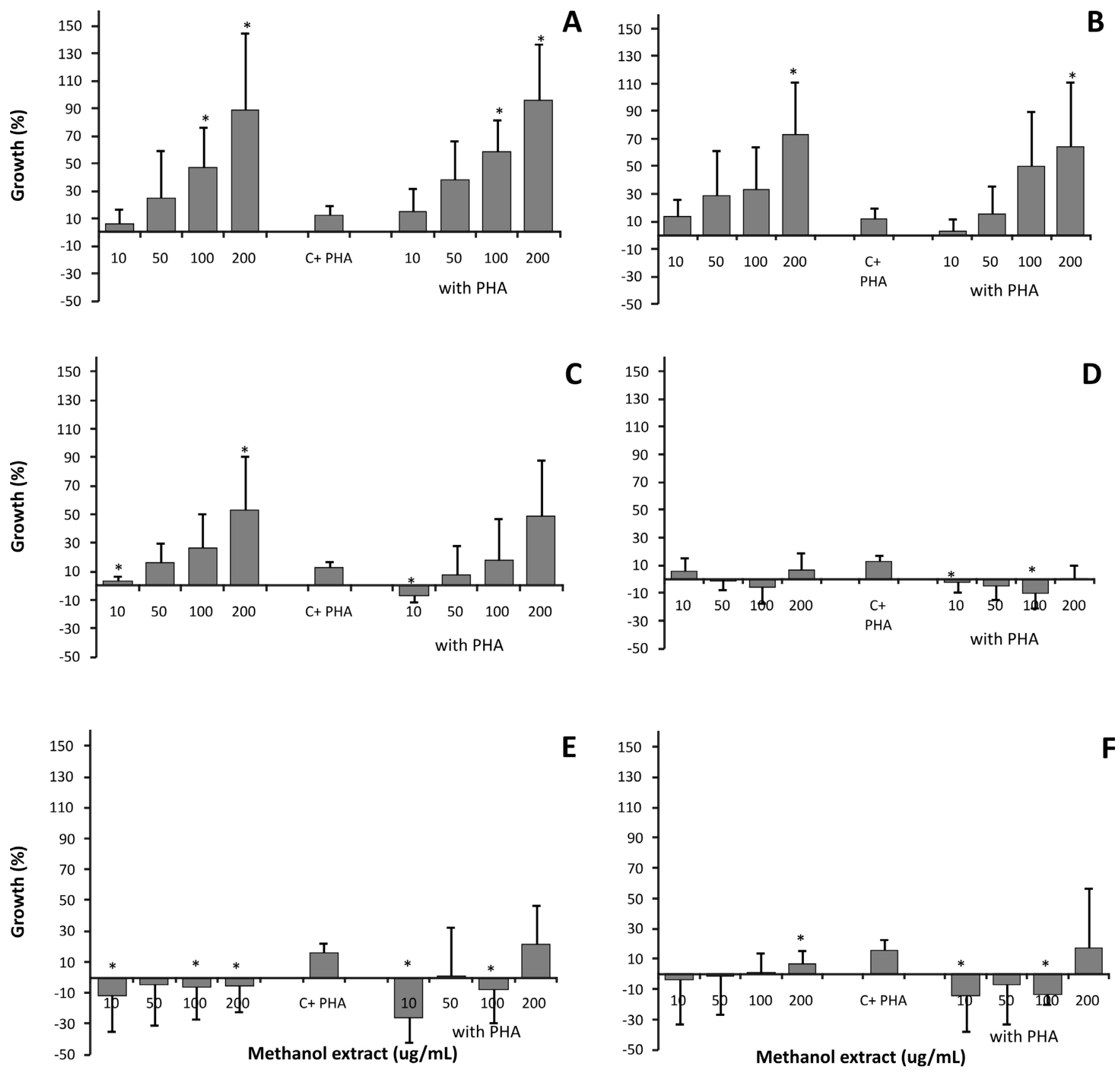

FIGURE 1 - Percentage growth of murine spleen cells treated with methanol extracts from different medicinal plants, in the presence or absence of mitogenic stimulation with phytohemagglutinin (PHA), for 72 hours at $37{ }^{\circ} \mathrm{C}$ and $5 \% \mathrm{CO}_{2}$. A: Calophyllum brasiliense; B: Ipomea pes-caprae; C: Matayba elaeagnoides; D: Maytenus robusta; E: Rubus imperialis, F: Vernonia scorpioides; C+PHA: positive control phytohemagglutinin (PHA), ${ }^{*} \mathrm{p}<0.05$ compared to $\mathrm{C}+\mathrm{PHA}$. Results are presented as the mean and standard deviation of four experiments performed in triplicate.

in the literature as inhibitors of human lymphocytes proliferation (Moiteiro et al., 2001; Brochado et al., 2003; Arokiyaraj et al., 2007), the action of these compounds appears to be inhibited by other compounds with immunostimulating effects, such as alkaloids (Sheng, Bryngelsson, Pero, 2000), since the results obtained showed an increase in cell proliferation and possibly activation of $\mathrm{T}$ lympho- cytes. Given the finding of the stimulating lymphocyte response and that the literature describes the betulinic acid, also present in this species, as a promising anticancer agent against melanoma by inhibiting the growth of cancer cells and inducing apoptosis (Pettit, 1996), the continuity of studies with fractions and isolated compounds of this plant can contribute to advances in the field of immunotherapy. 

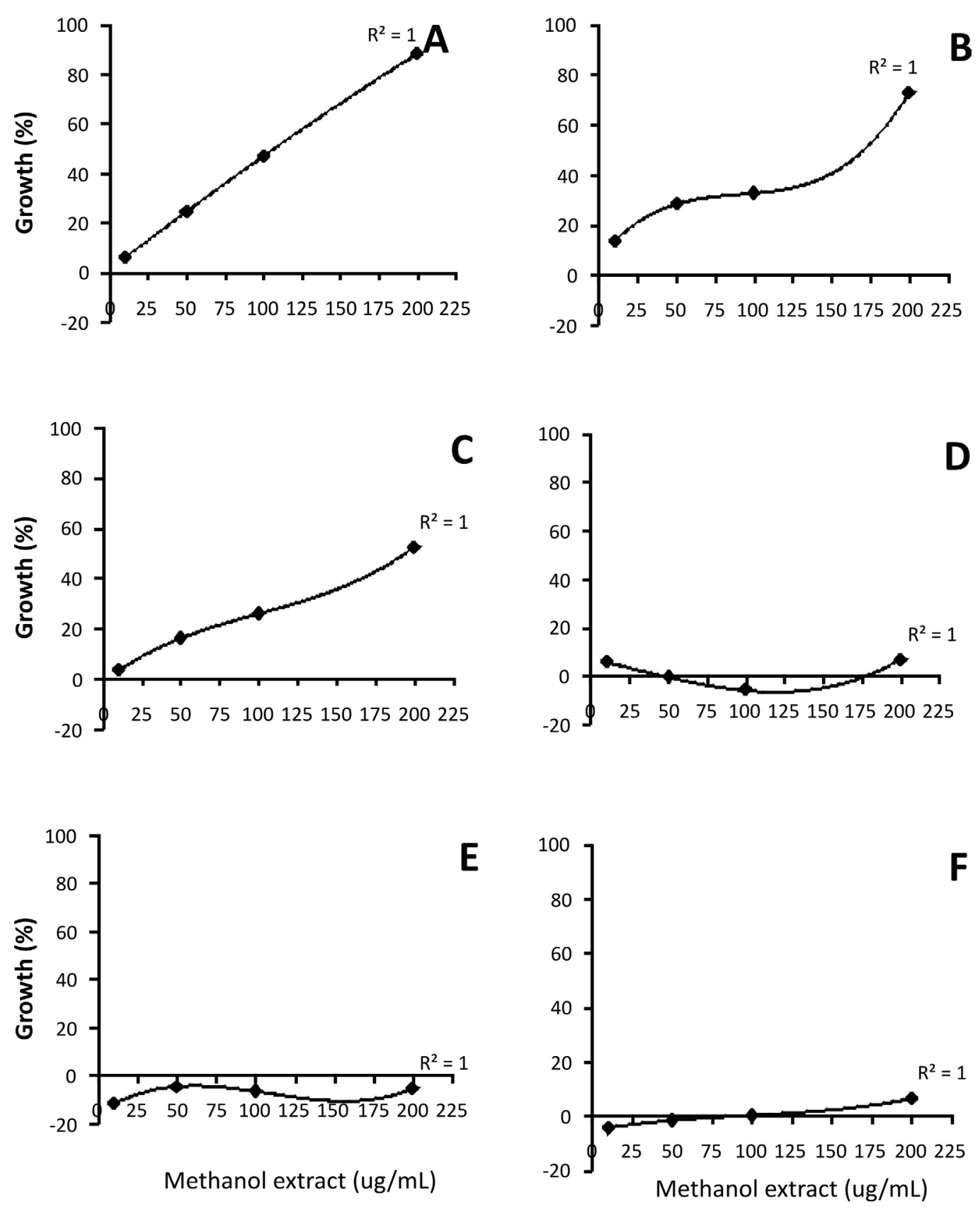

FIGURE 2 - Dose-response curve of methanol extracts from different medicinal plants in the proliferation assay with murine spleen cells for 72 hours at $37{ }^{\circ} \mathrm{C}$ and $5 \% \mathrm{CO}_{2}$. A: Calophyllum brasiliense; B: Ipomea pes-caprae; C: Matayba elaeagnoides; D: Maytenus robusta; E: Rubus imperialis, F: Vernonia scorpioides; $\mathrm{R}^{2}$ : coefficient of determination. Results are presented as the mean of four experiments performed in triplicate.

The methanol extract of M. elaeagnoides showed dose-dependent induction of spleen cell proliferation (Figures $1 \mathrm{C}$ and $2 \mathrm{C}$ ). The average percentage of cell growth was from 3.4 to $52.7 \%$ and -7.0 to $48.8 \%$, for extract alone and extract combined with PHA in cell culture, respectively. Under both culture conditions, the extract at $10 \mu \mathrm{g} / \mathrm{mL}$ induced significantly lower cell growth than the positive control PHA $(12.5 \%)(\mathrm{p}=0.03)$, while at $200 \mu \mathrm{g} / \mathrm{mL}$ the extract induced higher cell growth than the positive control $(\mathrm{p}<0.02)$. These data suggest that there is greater activation of T lymphocytes in the presence of high concentrations of the extract.

Several substances were previously isolated from the methanol extract of the bark of $M$. elaeagnoides, including steroids, coumarins, triterpenes (lupeol, $\alpha$ - and $\beta$ - amyrin, betulin), sitosterol, scopoletin, and flavonoids, among 
others (Souza, 2006). Although the coumarins extracted from other medicinal plants have shown no influence on the proliferation of human lymphocytes (Shimoda et al., 1998) whereas flavonoids and triterpenes inhibited the proliferation of these cells (Patocka, 2003; Moiteiro et al., 2001; Reyes et al., 2006; Arokiyaraj et al., 2007), betulin, another compound present in M. elaeagnoides, has shown mitogenic activity and the ability to induce and modulate cytokine production in cultured human cells (Zdzisińska et al., 2003).

The methanol extract of $M$. robusta induced the average rate of cell growth by $-5.8 \%$ to $7.0 \%$ for the extract alone and $-10.2 \%$ to $0.6 \%$ for the extract plus PHA in cell culture (Figure 1D) yielding a dose-dependent response (Figure 2D). The positive control of cell growth was $12.5 \%$, differing significantly between the extract at 10 and $200 \mu \mathrm{g} / \mathrm{mL}$, with both concentrations being responsible for the inhibition of cell growth induced by the mitogen $(\mathrm{p}=0.02)$. These results suggest that the $M$. robusta extract has compounds that inhibit the proliferative activity of murine spleen cells, while also inhibiting the mitogenic activity of PHA.

Phytochemical analysis of $M$. robusta demonstrated that it contains triterpene and phenolic compounds, as does Maytenus ilicifolia, popularly known in Brazil as "espinheira-santa" (Niero et al., 2001; Jorge et al., 2004). The triterpene friedelin appears to be the main component responsible for the action of this species against ulcers and gastritis, while in other plants it has been associated to inhibition of human lymphocyte proliferation (Moiteiro et al., 2001; Arokiyaraj et al., 2007). The presence of this triterpene in $M$. robusta suggests that the biological activity of this compound is predominant over other compounds in the murine spleen cell culture.

The inhibition of murine spleen cell proliferation was also observed with methanol extract of $R$. imperialis, with average growth of $-11.8 \%$ to $-4.4 \%$ for extract alone and $-26.2 \%$ to $21.6 \%$ for extract with the mitogen in cell culture (Figure 1E). No dose-response relationship was found under either of the culture conditions (Figure 2E), with results reaching significance versus the positive control of cell proliferation (15.9\%) when the extract was used at both 10 and $100 \mu \mathrm{g} / \mathrm{mL}(\mathrm{p}<0.04)$.

$R$. imperialis has triterpene constituents including ichigosídeo niga-F-1, tormentic and 23-hydroxy-tormentic acid (Niero et al., 1999). The inhibitory effect on the proliferation of murine spleen cells treated with $R$. imperialis methanol extract in this study confirmed the reports in the literature regarding the inhibitory activity of triterpenes on human lymphocyte proliferation (Moiteiro et al., 2001; Brochado et al., 2003; Arokiyaraj et al., 2007). Further studies with fractions and substances isolated from this species could identify those responsible for this inhibitory activity.

The last plant analyzed was $V$. scorpioides, which also showed inhibition of cell proliferation. The average growth obtained was $-4.1 \%$ to $6.7 \%$ with the methanol extract alone and $-13.9 \%$ to $16.9 \%$ with combined extract and PHA in cell culture (Figure 1F). Again, no dose-response relationship was observed under either of the culture conditions (Figure 2F), with a significance result only for the extract at $100 \mu \mathrm{g} / \mathrm{mL}$ versus the positive control of cell proliferation $(15.9 \%)(\mathrm{p}<0.04)$.

Although it was not possible to confirm the cytotoxic activity of the $V$. scorpioides extract in this study, the literature has reported this activity in different models, typically related to the presence of sesquiterpene lactones (Pagno et al., 2006; Buskühl, 2007), as well as another compound isolated from the plant, polyacetylene 5-octa-2,4,6-triinylfuran-2(5H)-one (Buskühl, 2007). The cytotoxic activity of sesquiterpene lactones and polyacetylene obtained from the dichloromethane fraction of $V$. scorpioides on Hela cells has recently been reported, with induction of apoptosis and increased expression of caspase 3 by polyacetylene (Buskühl, 2007). The dichloromethane fraction of this species increased the influx of neutrophils into the peritoneal cavity in mice with Ehrlich tumor, completely inhibiting the development of the tumor (Pagno et al., 2006).

The study of suppressor or stimulatory effects on cell proliferation using specific methodologies and molecular techniques may contribute to the elucidation of the mechanisms involved in the effects observed. The evaluation of immune stimulation can be determined by markers of cellular activation and proliferation, such as CD69 (Maino, Suni, Ruitenberg, 1995; Craston et al., 1997) and KI67 (Starborg et al., 1996; Scholzen, Gerdes, 2000; Kausch et al., 2003). In contrast, inhibition of cell proliferation and cytotoxic effect may assessed by the use of specific methodologies for the identification of necrosis and apoptosis such as LDH dosage in the supernatant of cell culture (Cruz-Chamorro et al., 2006) and detection of caspase 3 by immunocytochemistry (Krajewska et al., 1997) or through the release of p-nitroalinine (Posmantur, Wang, Gilbertsen, 1998).

In short, the need for control and equilibrium between the activities of suppression and stimulation of immune response for proper functioning of the immune system, has promoted the identification and characterization of natural compounds with immunomodulatory activity as an area of research interest (Phillipson, 2003). The characterization of medicinal plants from the Brazilian flora presented in this study should guide further studies 
on the theme which enable identification of compound(s) responsible for the most promising activities observed, i.e. the stimulating action on the proliferation of murine spleen cell by methanol extracts of $C$. brasiliense, I. pes-caprae and $M$. elaeagnoides, and the inhibitory action of extracts of $M$. robusta $R$. imperialis and $V$. scorpioides, as well as the mechanisms underlying these biological properties.

\section{REFERENCES}

ANDRADE, F. S.; LEMOS, M.; COMUNELLO, E.; NOLDIN, F. V.; CECHINEL FILHO, V.; NIERO, R. Evaluation of the antiulcerogenic activity of Maytenus robusta (Celastraceae) in different experimental ulcer models. J. Ethnopharmacol., v.113, n.2, p.252-257, 2007.

ARDENGHI, J.; KANEGUSUKU, M.; NIERO, R.; MONACHE, F. D.; CECHINEL FILHO, V.; SOUZA, M. M. Analysis of the mechanism of antinociceptive action of niga-ichigoside F1 obtained from Rubus imperialis (Rosaceae). J. Pharm. Pharmacol., v.58, n.12, p.1669-1175, 2006.

AROKIYARAJ, S.; PERINBAM, K.; AGASTIAN, P.; BALARAJU, K. Immunosuppressive effect of medicinal plants of Kolli hills on mitogen-stimulated proliferation of the human peripheral blood mononuclear cells in vitro. Indian J. Pharmacol., v.39, n.4, p.180-183, 2007.

BOYUM, A. Isolation of mononuclear cells and granulocytes from human blood. Isolation of mononuclear cells by one centrifugation, and of granulocytes by combining centrifugation and sedimentation at 1 g. Scand. J. Clin. Lab. Invest., v.21, suppl.97, p.77-89, 1968.

BROCHADO, C. O.; DE ALMEIDA, A. P.; BARRETO, B. P.; COSTA, L. P.; RIBEIRO, L. S.; PEREIRA, R. L. C.; KOATZ, V. L. G.; COSTA, S. S. Flavonol robinobiosides and rutinosides from Alternanthera brasiliana (Amaranthaceae) and their effects on lymphocyte proliferation in vitro. $J$. Braz. Chem. Soc., v.14, n.3, p.449-451, 2003.

BUFFON, D. E. Isolamento e identificação de princípios ativos de Calophyllum brasiliense Camb. (CLUSIACEAE). Itajaí, 2005. 84p. [Master's Degree Dissertation in Pharmaceutical Sciences. University of Vale do Itajaí]. Available at: $<$ http:// Siaibib01.univali.br/pdf/Daniela Enilda Buffon.pdf $>$. Accessed on: 15 May 2008.
BUSKÜHL, H. Avaliação in vitro do mecanismo de ação citotóxico de lactonas sesquiterpênicas e outras substâncias isoladas de Vernonia scorpioides (LAM) PERS. Itajaí, 2007. 117 p. [Master's Degree Dissertation in Pharmaceutical Sciences. University of Vale do Itajaí]. Available at: $<$ http:// Siaibib01.univali.br/pdf/Humberto Buskuhl.pdf $>$. Accessed on: 14 May 2008.

CECHINEL FILHO, V. Principais avanços e perspectivas na área de produtos naturais ativos: estudos desenvolvidos no NIQFAR/UNIVALI. Quim. Nova, v.23, n.5, p.680-685, 2000 .

CECHINEL FILHO, V.; YUNES, R. A. Estratégias para a obtenção de compostos farmacologicamente ativos a partir de plantas medicinais: conceitos sobre modificação estrutural para otimização da atividade. Quim. Nova, v.21, n.1, p.99-105, 1998.

CRASTON, R.; KOH, M.; DERMOTT, A.; RAY, N.; PRENTICE, H. G.; LOWDELL, M. W. Temporal dynamics of CD69 expression on lymphoid cells. J. Immunol. Methods, v. 209, n.1, p. 37-45, 1997.

CRUZ-CHAMORRO, L.; PUERTOLLANO, M. A.; PUERTOLlANO, E.; CIENFUEGOS, G. A.; PABLO, M. A. In vitro biological activities of magainin alone or in combination with nisin. Peptides, v.27, n.6, p.1201-1209, 2006.

DENIZOT, F.; LANG, R. Rapid colorimetric assay for cell growth and survival: modifications to the tetrazolium dye procedure giving improved sensitivity and reliability. $J$. Immunol. Methods, v.89, n.2, p.271-277, 1986.

GASPAROTTO Jr., A.; MISLAINE, B. A.; IZABEL, C. P.; CORTEZ, A. G.; NAKAMURA, C. V.; PRADO, D. B.; RODRIGUES, E.; FERREIRA, A. G. Estudo fitoquímico e avaliação da atividade moluscicida do Calophyllum brasiliense CAMB (Clusiaceae). Quim. Nova, v.28, n.4, p.575-578, 2005.

HOStettmanN, K.; QUEIROZ, E. F.; VIEIRA, P. C. Princípios ativos de plantas superiores. São Carlos: Edufscar, 2003. p.9-43.

ISAIAS, D. E. B.; NIERO, R.; NOLDIN, V. N.; BUZZI, F. C.; YUNES, R. A.; DELLE-MONACHE, F.; CECHINEL FILHO, V. Pharmacological and phytochemical investigation of different parts of Calophyllum brasiliense (Clusiaceae). Pharmazie, v.59, n.11, p.879-881, 2004. 
ITO, C.; ITOIGAWA, M.; MISHINA, Y; CECHINEL FILHO, V.; ENJO, F.; TOKUDA, H.; NISHINO, H.; FURUKAWA, H. Chemical constituents of Calophyllum brasiliense. 2. Structure of three new coumarins and cancer chemopreventive activity of 4-substituted soumarins. J. Nat. Prod., v.66, n.3, p.368-371, 2003.

JORGE, R. M.; LEITE, J. P.; OLIVEIRA, A. B.; TAGLIATI, C. A. Evaluation of antinociceptive, anti-inflammatory and antiulcerogenic activities of Maytenus ilicifolia. J. Ethnopharmacol., v.94, n.1, p.93-100, 2004.

KAUSCH, I.; LINGNAU, A.; ENDL, E.; SELLMANN, K.; DEINERT, I.; RATLIFF, T. L.; JOCHAM, D.; SCZAKIEL, G.; GERDES, J.; BÖHLE, A. Antisense treatment against Ki-67 mRNA inhibits proliferation and tumor growth in vitro and in vivo. Int. J. Cancer, v.105, n.5, p.710-716, 2003.

KIMURA. S.; ITO, C.; JYOKO, N.; SEGAWA, H.; KURODA, J.; OKADA, M.; ADACHI, S.; NAKAHATA, T.; YUASA, T.; CECHINEL FILHO, V.; FURUKAWA, H.; MAEKAWA $\mathrm{T}$. Inhibition of leukemic cell growth by a novel anti-cancer drug (GUT-70) from Calophyllum brasiliense that acts by induction of apoptosis. Int. J. Cancer, v.113, n.1, p.158$165,2005$.

KRAJEWSKA, M.; WANG, H. G.; KRAJEWSKI, S.; ZAPATA, J. M.; SHABAIK, A.; GASCOYNE, R.; REED, J. C. Immunohistochemical analysis of in vivo patterns of expression of CPP32 (Caspase-3), a cell death protease. Cancer Res., v.57, n.8, p.1605-1613, 1997.

KROGH, R.; KROTH, R.; BERTI, C.; MADEIRA, A. O.; SOUZA, M. M.; CECHINEL FILHO, V.; DELLEMONACHE, F.; YUNES, R. A. Isolation and identification of compounds with antinociceptive action from Ipomoea pes-caprae (L.) R. Br. Pharmazie, v.54, n.6, p.464-466, 1999.

KUHLMANN, M. K.; HORSCH, E.; BURKHARDT, G.; WAGNER, M.; KÖHLER, H. Reduction of cisplatin toxicity in cultured renal tubular cells by the biflavonoid quercitin. Arch. Toxicol., v.72, n.8, p.536-540, 1998.

LIMA, H. C. Fatos e mitos sobre imunomoduladores. An. Bras. Dermatol., v.82, n.3, p.207-221, 2007.

LORENZI, H. Plantas Daninhas do Brasil: terrestres, aquáticas parasitas e tóxicas. 3.ed. São Paulo: Instituto Plantarum, 2000. p.208-209.
MAINO, V. C.; SUNI, M. A.; RUITENBERG, J. J. Rapid flow cytometric method for measuring lymphocyte subset activation. Cytometry, v.20, n.2, p.127-133, 1995.

MANOSROI, A.; SARAPHANCHOTIWITTHAYA, A.; MANOSROI, J. Immunomodulatory activities of Clausena excavate Burm. f. wood extracts. J. Ethnopharmacol., v.89, n.1, p.155-160, 2003.

MEHROTRA, S.; MISHRA, K. P.; MAURYA, R.; SRIMAL, R. C.; YADAV, V. S.; PANDEY, R.; SINGH, V. K. Anticellular and immunosuppressive properties of ethanolic extract of Acorus calamus rhizome. Int. Immunopharmacol., v.3, n.1, p.53-61, 2003.

MOITEIRO, C.; JUSTINO, F.; TAVARES, R.; MARCELO CURTO, M. J.; FLORENCIO, M. H.; NASCIMENTO, M. S.; PEDRO, M.; CERQUEIRA, F.; PINTO, M. M. Synthetic secofriedelane and friedelane derivatives as inhibitors of human lymphocyte proliferation and growth of human cancer cell lines in vitro. J. Nat. Prod., v.64, n.10, p.1273-1277, 2001.

MONTEIRO, M. H.; GOMES-CARNEIRO, M. R.; FELZENSZWALB, I.; CHAHOUD, I.; PAUMGARTTEN, F. J. Toxicological evaluation of a tea from leaves of Vernonia condensata. J. Ethnopharmacol., v.74, n.2, p.149$157,2001$.

MOSMANN, T. Rapid colorimetric assay for cellular growth and survival: application to proliferation and cytotoxicity assays. J. Immunol. Methods, v.65, n.1-2, p.55-63, 1983.

NEWMAN, D. J.; CRAGG, G. M. Natural products as sources of new drugs over the last 25 years. J. Nat. Prod., v.70, n.3, p.461-477, 2007.

NIERO, R.; CECHINEL FILHO, V.; SOUZA, M. M.; MONTANARI, J. L.; YUNES, R. A.; MONACHE F. D. Antinociceptive activity of niga-ichigoside F1 from Rubus imperialis. J. Nat. Prod., v.62, n.8, p.1145-1146, 1999.

NIERO, R.; KANEGUSUKU, M.; SOUZA, M. M.; YUNES, R. A.; CECHINEL FILHO, V. Antinociceptive action of extracts and fractions from Rubus imperialis (Rosaceae). Therapie, v.57, n.3, p.242-245, 2002.

NIERO, R.; MOSER, R.; BUSATO, A. C. B.; YUNES, R. A.; REIS, A.; CECHINEL FILHO, V. A comparative chemical study of Maytenus ilicifolia Mart. Reiss and Maytenus robusta Reiss (Celastraceae). Z. Naturforsch., v.56, n.1-2, p.158-161, 2001. 
NIERO, R.; MAFRA, A. P.; LENZI, A. C.; CECHINEL-FILHO, V.; TISCHER, C. A.; MALHEIROS, A.; DE SOUZA, M. M.; YUNES, R. A.; DELLE-MONACHE, F. A new triterpene with antinociceptive activity from Maytenus robusta. Nat. Prod. Res., v.20, n.14, p.1315-1320, 2006.

NOLDIN, V. F.; BUFFON, D.; CECHINEL FILHO, V. Gênero Calophyllum: Importância química e farmacológica. Quím. Nova, v.29, n.3, p.549-554, 2006.

PAGNO, T.; BLIND, L. Z.; BIAVATTI, M. W.; KREUGER, M. R. Cytotoxic activity of the dichloromethane fraction from Vernonia scorpioides (Lam.) Pers. (Asteraceae) against Ehrlich's tumor cells in mice. Braz. J. Med. Biol. Res., v.39, n.11, p.1483-1491, 2006.

PANDIMA DEVI, K.; SAI RAM, M.; SREEPRIYA, M.; ILAVAZHAGAN, G.; DEVAKI, T. Immunomodulatory effects of Premna tomentosa extract against Cr(VI) induced toxicity in splenic lymphocytes - an in vitro study. Biomed. Pharmacother., v.57, n.2, p.105-108, 2003.

PATOCKA, J. Biologically active pentacyclic triterpenes and their current medicine signification. J. Appl. Biomed., v.1, p.7-12, 2003

PETTIT, G. R. Progress in the discovery biosynthetic anticancer drugs. J. Nat. Prod., v.59, n.8, p.812-821, 1996.

PHILLIPSON, J. D. 50 years of medicinal plant research - every progress in methodology is a progress in science. Planta Med., v.69, n.6, p.491-495, 2003.

PONGPRAYOON, U.; BOHLIN, L.; SANDBERG, F.; WASUWAT, S. Inhibitory effect of extract of Ipomoea pescaprae on guinea-pig ileal smooth muscle. Acta Pharm. Nord., v.1, n.1, p.41-44, 1989.

PONGPRAYOON, U.; BOHLIN, L.; WASUWAT, S. Neutralization of toxic effects of different crude jellyfish venoms by an extract of Ipomoea pes-caprae (L.) R. Br. J. Ethnopharmacol., v.35, n.1, p.65-69, 1991.

POSMANTUR, R.; WANG, K. K. W.; GILBERTSEN, R. B. Caspase-3-like activity is necessary for il-2 release in activated Jurkat t-cells. Exp. Cell Res., v.244, n.1, p.302309, 1998 .
REYES, C. P.; NÚNEZ, M. J.; JIMÉNEZ, I. A.; BUSSEROLLES, J.; ALCARAZ, M. J.; BAZZOCCHI, I. L. Activity of lupane triterpenoids from Maytenus species as inhibitors of nitric oxide and prostaglandin. Bioorg. Med. Chem., v.14, n.5, p.1573-1579, 2006.

RISCO, E.; GHIA, F.; VILA, R.; IGLESIAS, J.; ALVAREZ, E.; CANIGUERAL, S. Immunomodulatory activity and chemical characterization of sangre de drago (dragon's blood) from Croton lechleri. Planta Med., v.69, n.9, p.785794, 2003.

ROCHA, K. C.; GORESCO, R. A. G.; BELTRAME, R. L. Metodologia laboratorial para estudo da resposta imune celular. In: VAZ, A. J.; KIOKO, T. BUENO, E. C. (Eds.). Imunoensaios: fundamentos e aplicações. Rio de Janeiro: Guanabara Koogan, 2007. p.119-131.

ROSEGHINI, R.; MOREIRA, P.; VALE, V.; PINHEIRO, A. M.; COSTA, J. F.; BITTENCOURT, T.; NASCIMENTO, I.; SCHAER, R.; VELOZO, E.; EL-BACHÁ, R.; MEYER, R.; FREIRE, S. Different effects of arborinine alkaloid obtained from Brazilian Erthela baihensis on spleen and thymus cells stimulated in vitro with different mitogens. Immunopharmacol. Immunotoxicol., v.28, n.2, p.361-376, 2006.

SCHOLZEN, T.; GERDES, J. The Ki-67 protein: from the known and the unknown. J. Cell Physiol., v.182, n.3, p.311$322,2000$.

SHENG, Y.; BRYNGELSSON, C.; PERO, R. W. Enhanced DNA repair, immune function and reduced toxicity of C-MED-100, a novel aqueous extract from Uncaria tomentosa.J. Ethnopharmacol., v.69, n.2, p.115-126, 2000.

SHIMODA, H.; MATSUDA, H.; YAMAHARA, J.; YOSHIKAWA, M. Development of bioactive functions in Hydrangeae Dulcis folium. VII. Immunomodulatory activities of thunberginol $\mathrm{A}$ and related compounds on lymphocyte proliferation. Biol. Pharm. Bull., v.21, n.8, p.809-813, 1998.

SILVA, K. L; SANTOS, A. R. S.; MATTOS, P. E. O; YUNES, R. A; DELLE-MONACHE, F.; CECHINEL FILHO, V. Chemical composition and analgesic activity of Calophyllum brasiliense. Therapie, v.56, n.4, p.431-434, 2001. 
SOUZA, M. M.; MADEIRA, A.; BERTI, C.; KROGH, R.; YUNES, R. A.; CECHINEL FILHO, V. Antinociceptive properties of the methanolic extract obtained from Ipomoea pes-caprae (L.) R. Br. J. Ethnopharmacol., v.69, n.1, p.8590, 2000.

SOUZA, M. M.; SCHLEMPER, V.; JESUS, R.; CECHINEL FILHO, V. Analgesic profile of hydroalcoholic extract obtained from Marruium vulgare. Phytomedicine, v.5, n.2, p.111-113, 1998.

SOUZA, M. T. Estudo fitoquímico e avaliação de atividade biológica de matayba elaeagnoides RADALK. Itajaí, 2006. 87 p. [Master's Degree Dissertation in Pharmaceutical Sciences. University of Vale do Itajaí]. Available at: $<$ http:// Siaibib01.univali.br/pdf/Michel Thomaz de Souza.pdf>. Accessed on: 15 may 08.

SOUZA, M. T.; BUZZI, F. C; CECHINEL-FILHO, V.; HESS, S; DELLE MONACHE, F.; NIERO, R. Phytochemical and antinociceptive properties of Matayba elaeagnoides. Z. Naturforsch., v.62, n.7-8, p.550-554, 2007.

SOUZA-FAGUNDES, E. M.; QUEIROZ, A. B. R.; MARTINS FILHO, O. A.; GAZZINELLI, G.; CORREA-OLIVEIRA, R.; ALVES, T. M. A.; ZANI, C. L. Screening and fractionation of plant extracts with antiproliferative activity on human peripheral blood mononuclear cells. Mem. Inst. Oswaldo Cruz, v.97, n.8, p.1207-1212, 2002.

S R I WANTHANA，B.; TREESANGSRI, W.; BORIBOONTRAKUL, B.; NIUMSAKUL, S.; CHAVALITTUMRONG, P. In vitro effects of Thai medicinal plants on human lymphocyte activity. Songklanakarin J. Sci. Technol., v.29, n.1, p.17-28, 2007.

STARBORG, M.; GELL, K.; BRUNDELL, E.; HOOG, C. The murine Ki-67 cell proliferation antigen accumulates in the nucleolar and heterochromatic regions of interphase cells and at the periphery of the mitotic chromosomes in a process essential for cell cycle progression. J. Cell Sci., v.109, n.1, p.143-153, 1996.

VEROTTA, L.; APPENDINO, G.; JAKUPOVIC, J.; BOMBARDELLI, E. Hyperforin analogues from St. John's wort (Hypericum perforatum). J. Nat. Prod., v.63, n.3, p.412-415, 2000.
VIEGAS, J. R. C.; BOLZANI, V. S.; BARREIRO, E. J. Os produtos naturais e a química medicinal moderna. Quim. Nova, v.29, n.2, p.326-337, 2006.

WAGNER, H. Pesquisa fitomédica no novo milênio: tendências e mudanças. In: YUNES, R. A.; CECHINEL FILHO, V. (Eds.). Química de produtos naturais, novos fármacos e a moderna farmacognosia. Itajaí: Editora da UNIVALI, 2007. p.34-47.

WILASRUSMEE, C.; KITTUR, S.; SIDDIQUI, J.; BRUCH, D.; WILASRUSMEE, S.; KITTUR, D. In vitro immunomodulatory effects of ten commonly used herbs on murine lymphocytes. J. Alternative Compl. Med., v.8, n. 4, p.467-475, 2002.

YASNI, S.; YOSHIIE K.; ODA H.; SUGANO M.; IAMIZUMI K. Dietary Curcuma xanthorrhiza Roxb. increases mitogenic responses of splenic lymphocytes in rats, and alters populations of the lymphocytes in mice. J. Nut. Sci. Vitaminol., v.39, n.4, p.345-354, 1993.

YUNES, R. A.; CECHINEL FILHO, V. Plantas medicinais sob a ótica da química medicinal moderna. Chapecó: Argos, 2001. p.48-75.

YUNES, R. A.; CECHINEL FILHO, V. Novas perspectivas dos produtos naturais na química medicinal moderna. In: YUNES, R. A.; CECHINEL FILHO, V. (Eds.). Química de produtos naturais, novos fármacos e a moderna farmacognosia. Itajaí: UNIVALI, 2007. p.11-47.

ZDZISIŃSKA, B.; RZESKI, W.; PADUCH, R.; SZUSTERCIESIELSKA, A,; KACZOR, J.; WEJKSZA, K.; KANDEFER-SZERSZEŃ, M. Differential effect of betulin and betulinic acid on cytokine production in human whole blood cell cultures. Pol. J. Pharmacol., v.55, n.2, p.235238, 2003.

Received for publication on $04^{\text {th }}$ July 2008 Accepted for publication on $18^{\text {th }}$ November 2009 